\title{
Could de-stressing the brain be the solution for long-term weight loss?
}

\author{
Florian Seyfried ${ }^{1}$ and Mohammed K. Hankir ${ }^{2, *}$ \\ ${ }^{1}$ Department of General, Visceral, Vascular and Pediatric Surgery, University Hospital Wuerzburg, Wuerzburg, 97080 Bavaria, Ger- \\ many. \\ ${ }^{2}$ Department of Experimental Surgery, University Hospital Wuerzburg, Wuerzburg, 97080 Bavaria, Germany. \\ * Corresponding Author: \\ Dr. Mohammed K. Hankir, PhD, Centre of Operative Medicine, Oberduerrbacherstraße 6, Wuerzburg, 97080 Bavaria, Germany; \\ Tel.: +49 931201 31728; E-mail: hankir_m@ukw.de
}

ABSTRACT The obese brain is stressed and inflamed. This is mainly at the level of neurons and glial cells in the hypothalamus: a brain region where the adipokine leptin acts to control feeding and body weight. Relieving hypothalamic neuronal endoplasmic reticulum (ER) stress with the natural small molecule drugs celastrol or withaferin-A reverses the leptin resistance commensurate with obesity, producing a degree of weight loss found only with bariatric surgery. Here, recent evidence from rodent models of vertical sleeve gastrectomy (VSG) is brought to the fore which suggests that this particular bariatric surgical procedure may work in a similar fashion to celastrol and withaferin-A alongside remedying hypothalamic inflammation and gliosis. Thus, restoring and preserving healthy hypothalamic neuronal and glial cell function, be it by pharmacological or surgical means, ensures a negative energy balance in an environment constructed to promote a one - possibly through re-establishing communication between adipose tissue and the brain. doi: $10.15698 /$ cst2019.02.174

Received originally: 24.09.2018

in revised form: 16.01.2019,

Accepted 22.01.2019,

Published 25.01.2019.

Keywords: endoplasmic reticulum stress, gliosis, hypothalamus, inflammation, leptin resistance, obesity, vertical sleeve gastrectomy.
Abbreviations:
elF2a-elongation initiation factor 2 alpha,
$E R$ - endoplasmic reticulum,
FXR - farnesoid $X$ receptor,
GABA - gamma amino butyric acid,
GLP-1 - glucagon-like peptide 1,
IKK- $\beta$ - inhibitor of kappa beta kinase beta,
IL - interleukin,
HSF1 - heat shock factor 1,
$N F-K \beta$ - necrosis factor kappa beta, PERK - protein kinase $R$ (PKR)-like ER kinase,
PTP1B - protein tyrosine phosphatase $1 B$, $P G C-1 \alpha$ - peroxisome proliferator-
activated receptor gamma coactivator 1- alpha,
SOCS3 - suppressor of cytokine signaling 3 ,
TGR5 - Takeda G-protein 5 receptor,
TLR4 - toll-like receptor 4,
TNF- $\alpha$ - tumor necrosis factor alpha,
UCP1 - uncoupling protein 1,
VSG - vertical sleeve gastrectomy,
vWAT - visceral white adipose tissue.

\section{INTRODUCTION}

One just needs to take a look at a typical vending machine (often found in hospitals) to appreciate what has happened to our food and drink. The relatively sudden widespread ease of access to energy-dense meals, combined with a generally less active way of life and superimposed on a susceptible genetic background has fueled a steep rise in global obesity prevalence. This in turn has directly contributed to the increased incidence of chronic debilitating conditions such as type II diabetes, atherosclerosis, cardiovas- 
cular disease and certain cancers which are all major causes of premature death.

\section{ADIPOSE TISSUE AND INTESTINAL INFLAMMATION AS A CAUSE OF INSULIN RESISTANCE}

Early efforts to disentangle the close relationship between obesity and type II diabetes focused on the proinflammatory cytokine tumor necrosis factor alpha (TNF- $\alpha$ ) in visceral white adipose tissue (vWAT) [1]. A pronounced increase was found in various rodent models of obesity [1] and this marked the beginning of a powerful narrative in which increased visceral adiposity causes a state of chronic, low-grade systemic inflammation involving both the adaptive and innate immune systems. Subsequent rodent studies revealed in reverse chronological order that during obesity progression, antigen-presenting and IgG-releasing $B$ cells are the first to arrive in VWAT, possibly attracted by chemokines released from swelling adipocytes sensed by the mechanoreceptor transient receptor potential vanilloid 4 (TRPV4) [2], followed by the recruitment of cytotoxic CD8+ T cells and then by M2 macrophages $[3,4,5]$. These white blood cells all release a plethora of pro-inflammatory cytokines including macrophage-derived TNF- $\alpha$ [6] that interfere with insulin receptor signaling both locally in VWAT and distally in peripheral tissues such as the liver and skeletal muscle [7] (Figure 1).

It is now increasingly recognized that a complex immune response also takes hold in the gut from chronic consumption of a high-fat diet due to shifts in resident microbiota species. This engenders the downregulation of regulatory $\mathrm{T}$ cells (Treg ) and innate lymphoid cells (ILCS), which normally secrete the anti-inflammatory/intestinal barrier-protective cytokines interleukin 10 (IL-10) and IL-22, respectively, with the concomitant upregulation of cytotox- ic CD8+ and Th1 T cells, which secrete the proinflammatory and intestinal barrier-disrupting cytokine interferon gamma (IFN- $\gamma$ ) [8]. The loss of gut barrier integrity itself in obesity results in systemic endotoxemia which too contributes to vWAT macrophage activation, possibly through bacterially-derived lipopolysaccharide (LPS) acting on local toll-like receptor 4 (TLR4) $[8,9]$. Thus, we now know a great deal about the molecular and cellular underpinnings of obesity-induced insulin resistance, although this has yet to be translated into an effective immunebased therapy for type II diabetes in humans.

\section{HYPOTHALAMIC INFLAMMATION AS A CAUSE OF LEPTIN RESISTANCE}

At about the same time that inflammation in the VWAT of severely obese and diabetic ob/ob mice was discovered [1] the $o b$ gene encoding the adipokine leptin was itself cloned [10]. This generated considerable excitement about the prospects of a new and more effective obesity pharmacotherapy. However, it was soon realized that individuals with obesity are refractory to the appetite suppressing and weight lowering effects of exogenous leptin treatment [11]. Analogous to insulin resistance, inflammatory processes in the brain, specifically in hypothalamic neurons, would provide a link between obesity and the relatively newly coined term leptin resistance [12]. Furthermore, hypothalamic neuronal endoplasmic reticulum (ER) stress was also shown to develop upon chronic high-fat food consumption in mice, being both a cause and a consequence of proinflammatory inhibitor of kappa beta kinase beta (IKK- $\beta$ ) signaling [12]. That acute brain overload of the saturated fatty acid oleate was sufficient to increase hypothalamic necrosis factor kappa beta (NF-K $\beta$ ) transcriptional activity supported the concept that high-fat feeding first promotes
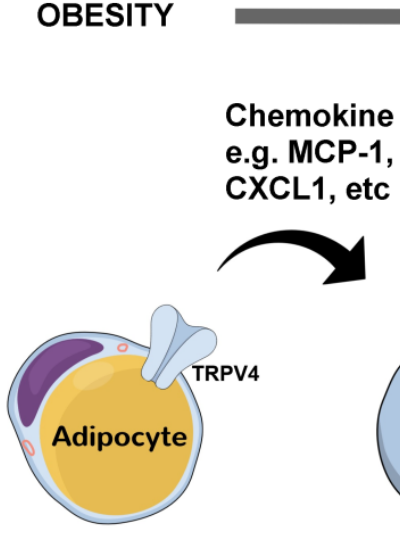

Antigen Presentation
Pro-inflammatory cytokine e.g. IFN-gamma
INSULIN RESISTANCE

FIGURE 1: Molecular and cellular processes linking obesity with systemic insulin resistance. Swelling (hyperplasic) visceral adipocytes in obesity have hyperactivated TRPV4 which leads to changes in gene expression (through extracellular related kinase $1 / 2$ signaling) including an increase in chemokine production. This sets into motion a sequence of molecular and cellular events ultimately leading to insulin resistance in hepatocytes and myocytes in part through inhibitory serine 120 and serine 210 phosphorylation of insulin receptor substrate 1 in these cells by TNF- $\alpha$. CXCL1 - chemokine (C-X-C motif) ligand 1, IFN-gamma - interferon gamma, MCP-1 - monocyte chemoattractant protein 1, TNF $\alpha$ - tumor necrosis factor alpha, TRPV4 - transient receptor potential vanilloid 4. 
hypothalamic neuronal inflammation and ER stress, followed by leptin resistance. Consequently, the rise in circulating leptin levels as fat mass increases fails to act as a negative feedback signal to maintain a stable body weight. Contrary to what might be expected however, ER stress does not affect leptin receptor folding in the ER and trafficking to the plasma membrane [13]. While a unifying mechanism for hypothalamic inflammation, ER stress and diminished leptin receptor signaling in obesity is still missing, the increased expression of protein tyrosine phosphatase 1B (PTP1B) caused by NF-K $\beta$ is a likely candidate [14]. This is because beyond the established inhibitory role of PTP1B in dephosphorylating the leptin receptor effector protein janus kinase 2 (JAK2) at the cell membrane [15], it also potentiates the inositol requiring enzyme 1 (IRE1) arm of the ER stress response through its phosphatase activity at the ER [16] (Figure 2A). Additionally/alternatively, NF-K $\beta$ could increase suppressor of cytokine signaling 3 (SOCS3) [12] and decrease mitofusion 2 [17] expression to directly interfere with leptin receptor signaling [18] and cause hypothalamic ER stress [19], respectively. Also, through the protein kinase $R$ (PKR)-like ER kinase (PERK) and eukaryotic elongation initiation factor 2 alpha (elF2- $\alpha$ ) arm of the ER stress response, a more stable SOCS3 isoform is produced by alternative translation which would serve to further exacerbate leptin resistance [20] (Figure 2B).

The brain's support and immune cells would then be added to the mix when it was shown that hypothalamic astrocytes and microglia become activated within days after placing rats and mice on a high-fat diet [21]. Subsequent and prior studies suggested that elevated circulating saturated fatty acids themselves act as pro-inflammatory signaling molecules on hypothalamic neurons and microglia through TLR4 [22-24]. In contrast, astrocytes appear to be activated by saturated fatty acids through a bystander effect $[22,24]$. Contributions of IKK- $\beta$ in hypothalamic neurons [12] and microglia [25] to promoting leptin resistance and obesity are now clear. Furthermore, hypothalamic microglial IKK- $\beta$ signaling promotes the recruitment of circulating CD169+ monocytes into the hypothalamus, which then adopt a microglia-like phenotype to further aggravate inflammation and perpetuate leptin resistance [25]. This, although controversial [26], could be mediated in part through the release of the chemokine fractalkine from hypothalamic neurons consequential to receiving TNF- $\alpha$ from neighboring glial cells [27]. Interestingly, IKK- $\beta$ signaling in hypothalamic astrocytes seems to serve a different kind of function by shortening their fine processes in the face of a high-fat diet leading to reduced gamma amino butyric acid (GABA) reuptake from the extra-synaptic space [28]. As a result, $G_{A B A_{B}}$ receptors are activated in nearby neurons decreasing their production of anorexigenic brainderived neurotrophic factor (BDNF) which ultimately causes hyperphagia and obesity $[28,29]$ Thus, the hypothalamic molecular and cellular perturbations in response to chronic high-fat diet consumption are multifaceted, involving a complex array of signaling molecules and cell types originating both peripherally and centrally which act in tandem to disrupt whole-body energy balance regulation (Figure 3).

\section{HYPOTHALAMIC ER STRESS RELIEVERS ARE POTENT WEIGHT LOSS COMPOUNDS}

Because of the pivotal role hypothalamic ER stress plays in leptin resistance and obesity development $[12,13,19,30]$, a screen was performed to identify small molecules which might promote weight loss through its amelioration [31]. By comparing the mouse hypothalamic transcriptomic response to obesity and ER stress-relieving chemical chaperones with that of human cell lines treated with a panel of FDA-approved drugs and other bioactive compounds [32], the thunder god vine root extract celastrol emerged as one that caused the most similar absolute changes. Next, in a three week feeding study performed on high-fat dietinduced obese mice, once daily intraperitoneal celastrol injections produced a striking $30 \%$ weight loss largely through reduced food intake. This is far greater than the 5$10 \%$ typically observed with currently prescribed obesity medications such as the 5 hydroxytryptamine $2 \mathrm{C}\left(5-\mathrm{HT} 2_{\mathrm{C}}\right)$ receptor agonist lorcaserin or the glucagon-like peptide 1 (GLP-1) analogue liraglutide and approaches that found with bariatric surgeries such as vertical sleeve gastrectomy (VSG) and Roux-en-Y gastric bypass (RYGB). That weight loss did not occur in leptin-deficient $o b / o b$ or leptin receptor-deficient $d b / d b$ mice treated with celastrol provided strong evidence that it acts as an endogenous leptin sensitizer. Accordingly, hypothalamic leptin receptor signaling was enhanced in wild-type mice after celastrol treatment alongside reduced ER stress although experiments with celastrol administered to mice lacking functional leptin receptors specifically in various nuclei of the hypothalamus [33] still need to be performed to draw definitive conclusions. Celastrol also impressively prevented weight gain in mice placed on a high-fat diet for a year and was well tolerated.

Motivated by this success, the same group of researchers went on to search for compounds which produce a similar gene expression profile as celastrol in mouse embryonic fibroblasts [34]. The winter cherry plant extract withaferin-A emerged as the best hit. Comparable to celastrol, withaferin-A produced approximately $20 \%$ weight loss in high-fat diet-induced obese mice in a three week feeding study largely by reducing food intake. Again, withaferin-A was minimally effective in $o b / o b$ and $d b / d b$ mice and reinstated the appetite suppressing effects of exogenous leptin treatment in otherwise leptin resistant, high-fat dietinduced obese mice. Finally, as with celastrol, hypothalamic leptin receptor signaling was enhanced and ER stress was reduced by withaferin-A. Notably, precisely how celastrol and withaferin A reverse hypothalamic ER stress in obesity remains unknown. For celastrol at least, this may be from direct inhibition of IKK- $\beta$ catalytic activity through targeting cysteine 179 in the activation loop [35] and/or noncompetitive inhibition of PTP1B [36]. Interestingly, unlike celastrol, withaferin-A does not inhibit PTP1B catalytic activity [36] which may explain why the former is the superi- 

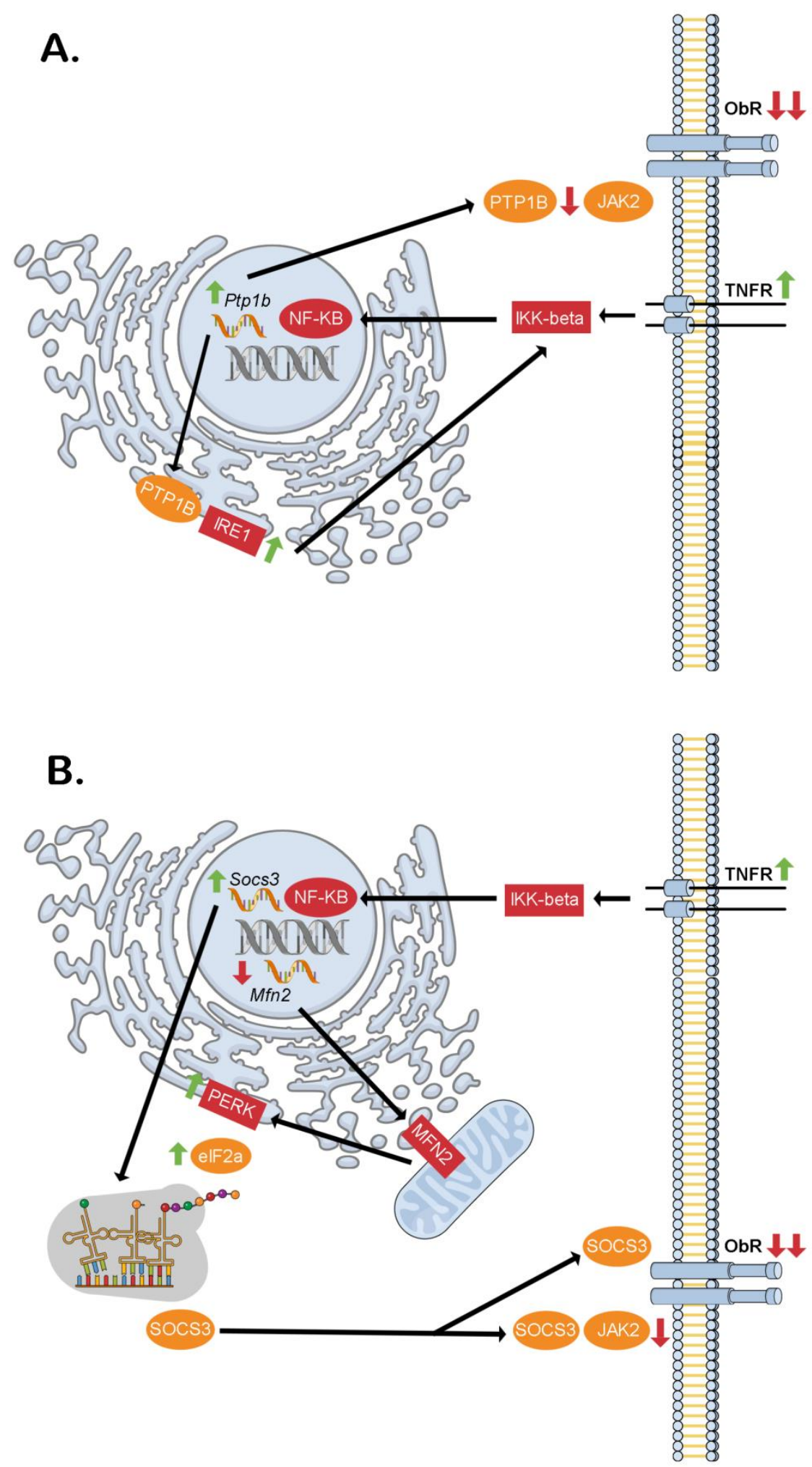

FIGURE 2: Proposed intracellular signaling cascades liking inflammation, ER stress and hypothalamic neuronal leptin resistance in obesity. (A) Through the dual phosphatase action of PTP1B at the ER (stimulatory on IRE1) and cell membrane (inhibitory on JAK2) downstream of TNF- $\alpha$ receptor activation, hypothalamic neuronal leptin receptor signaling may be blunted contributing to increased food intake and obesity. (B) Similarly, through the dual action of NF-KB of increasing Socs3 transcription and decreasing Mfn2 transcription, hypothalamic neuronal leptin receptor signaling may be blunted contributing to increased food intake and obesity. This would be through decreased mitochondrial MFN2 leading to reduced ERmitochondrial contacts thereby causing ER stress. The PERK-elF $2 \alpha$ arm of this response mediates alternative translation of Socs3 mRNA of a more stable SOCS3 variant, which lacks an amino terminus tail containing a lysine residue that is normally ubiquitinated sending the full-length SOCS3 to the proteasome for degradation. elF2a - elongation initiation factor 2 alpha, IKK-beta - inhibitor of kappa beta kinase beta, IRE1 inositol requiring enzyme 1 , JAK2 janus kinase 2, Mfn2 - Mitofusin-2, NK-KB - necrosis factor kappa beta, ObR - leptin receptor, PERK - protein kinase $R$ (PKR)-like ER kinase, PTP1B protein tyrosine phosphatase $1 B$ Socs3 - suppressor of cytokine signaling 3, TNFR - tumor necrosis factor receptor. or weight loss compound. It is also still unclear what effects both these molecules have on hypothalamic glial cells.

In addition to its central mode of action in suppressing energy (food) intake, celastrol has also been proposed to promote a negative energy balance by increasing energy expenditure through stimulating adipose tissue thermo- genesis [37]. This is thought to be from the stabilizing effect of celastrol on the protein-protein interaction between heat shock factor 1 (HSF1) and peroxisome proliferator-activated receptor gamma coactivator 1-alpha (PGC$1 \alpha)$, two transcription factors that induce a thermogenic gene expression program in adipocytes by binding to the 
Pgc1 $\alpha$ promoter [37]. Indeed, normal weight mice placed on a high-fat diet for two weeks and treated with low doses of celastrol were protected from weight gain associated with increased energy expenditure but no reductions in food intake [37]. Furthermore, the marked upregulation of thermogenic genes in adipose tissue caused by celastrol was not seen in HSF1-deficient mice. This peripheral mode of action for celastrol was however not supported by subsequent findings from mice deficient in uncoupling protein 1 (UCP1), the principal thermogenic effector in adipose tissue [38]. It is nevertheless still possible that UCP1independent thermogenesis contributes to celastrol's effects on body weight. These issues notwithstanding, there is genuine hope that natural, safe and effective obesity treatments are in the horizon. However, the effects of both celastrol and withaferin-A need to be evaluated in human individuals with obesity first before metabolic researchers will need to hang up their lab coats.

\section{VSG RELIEVES HYPOTHALAMIC INFLAMMATION, GLIOSIS, AND ER STRESS}

If the pharmacological and surgical forms of obesity treatment described above cause comparable magnitudes of weight loss, then it can be argued that they both have similar mechanisms of action. Indeed, recent studies on rats and mice in the context of obesity-associated infertility and hypertension have shown that VSG reduces hypothalamic inflammation [39, 40], gliosis [39], and ER stress [40]. Interestingly, there is also evidence from mice $[41,42]$, rats, [43] and humans [44] that like celastrol, VSG induces a thermogenic program in adipocytes although the functional relevance of this remains unclear.

In the study of Xiang et al. [39], Sprague Dawley rats were placed either on a standard chow diet or on a high-fat diet. After 16 weeks, half of the high-fat group was randomized to receive VSG whereas the remaining rats received sham surgery to control for the stress of laparotomy. The VSG-operated rats lost approximately $25 \%$ of their body weight after eight weeks, which is comparable to that of the human procedure, while the sham-operated groups continued to gain weight during this time period. Immunohistochemical analysis was then performed on hypothalamic sections. Levels of the chemokine monocyte chemoattractant protein 1 (MCP1) were decreased in the VSGoperated group compared to the sham-operated group on a high-fat diet and approached the levels found in the sham-operated group on the low-fat chow diet. Similar findings were made on the levels of pro-inflammatory phosphorylated signal transducer and activator of transcription 3 (pSTAT3) specifically in hypothalamic microglial cells.

In the study of McGavigan et al. [40], high-fat dietinduced obese C57BL/6J mice received either VSG or sham surgeries. A subgroup of sham-operated mice was then weight-matched to the VSG group by chronic caloric restriction - an important control to ensure any changes seen are not simply due to weight loss. All groups lost weight during the first two weeks postoperatively, highlighting the sensitivity of mice to surgical stress. However, by the $10^{\text {th }}$ week, VSG-operated mice weighed approximately $10 \%$ less than the sham-operated ad libitum fed mice, consuming significantly less food during this time period. Hypothalamic lysates were then prepared for Western Blot analysis. Levels of phosphorylated (activated) PERK and elF2- $\alpha$ were reduced in VSG mice, as was TNF- $\alpha$. This was not found in the weight-matched control group suggesting that reduced hypothalamic ER stress and inflammation are effects specific to VSG. A selective reduc-

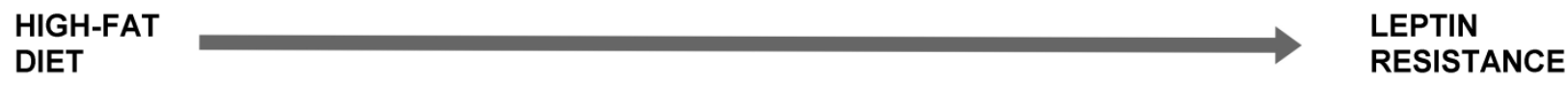
Pro-inflammatory cytokine

\section{Chemokine e.g. Fractalkine} e.g. TNF-alpha

Pro-inflammatory cytokine e.g. TNF-alpha

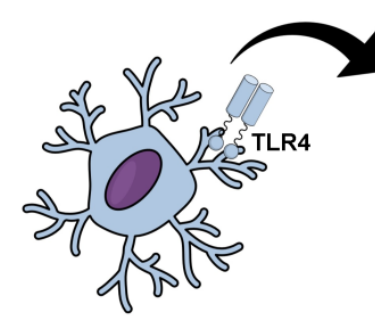

Microglia

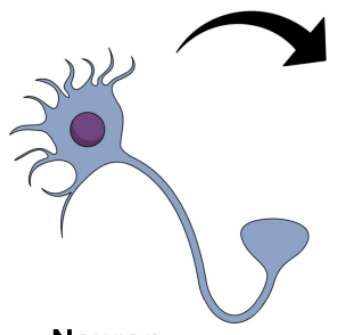

Neuron

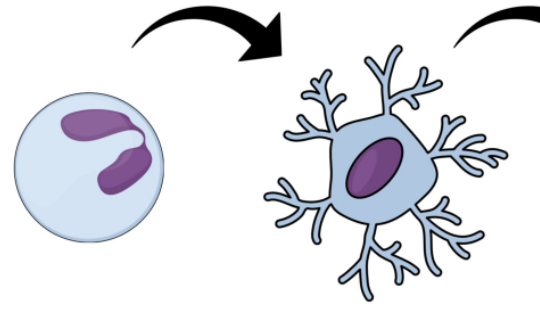

Monocyte

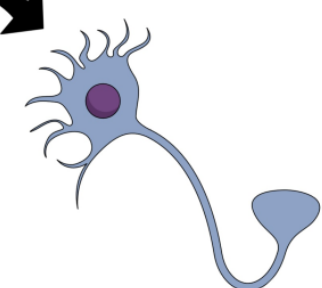

Neuron

FIGURE 3: Molecular and cellular processes linking chronic high-fat diet consumption with leptin resistance and obesity. The rise in circulating saturated fatty acids from chronic consumption of a high-fat diet leads to activation of TLR4 in hypothalamic microglia which then release pro-inflammatory cytokines such as TNF- $\alpha$. This in turn leads to the release of the chemokine fractalkine from adjacent neurons which recruits circulating monocytes into the hypothalamus and which then differentiate into activated microglia. A vicious cycle is thus initiated which progressively worsens leptin resistance in hypothalamic neurons contributing to increased food intake and obesity. TLR4 toll-like receptor 4, TNF-alpha - tumor necrosis factor alpha. 
tion in Adlercreutzia microbiota after VSG was proposed to provide the link between changes in gut anatomy and brain cellular pathology.

The studies of Xiang et al. and McGavigan et al., despite only being associational in nature, collectively provide persuasive evidence that VSG reduces hypothalamic inflammation, gliosis and/or ER stress in obesity (Figure 4). By extension, it can be reasonably inferred that this particular bariatric surgical procedure restores leptin sensitivity to cause marked and lasting weight loss. In support of this idea, VSG-operated rats and mice have lower circulating leptin levels compared to pair-fed controls with similar adiposity indicative of decreased leptin resistance [45],
[46]. Furthermore, VSG-operated rats are more responsive to the acute appetite suppressing effects of exogenous leptin treatment than pair-fed rats [45]. On the other hand, unlike celastrol [24] or withaferin-A [26] treatments, leptin receptor-deficient $f a / f a$ Zucker rats [47] and $d b / d b$ mice [48] still lose weight after VSG, suggesting that leptin is a dispensable/redundant mediator of its effects on wholebody energy balance. One potential way to resolve these inconsistencies is to induce hypothalamic ER stress and leptin resistance post-abdominal surgeries in rodents through intracerebroventricular administration of tunicamycin and to assess changes in feeding and body weight [13].

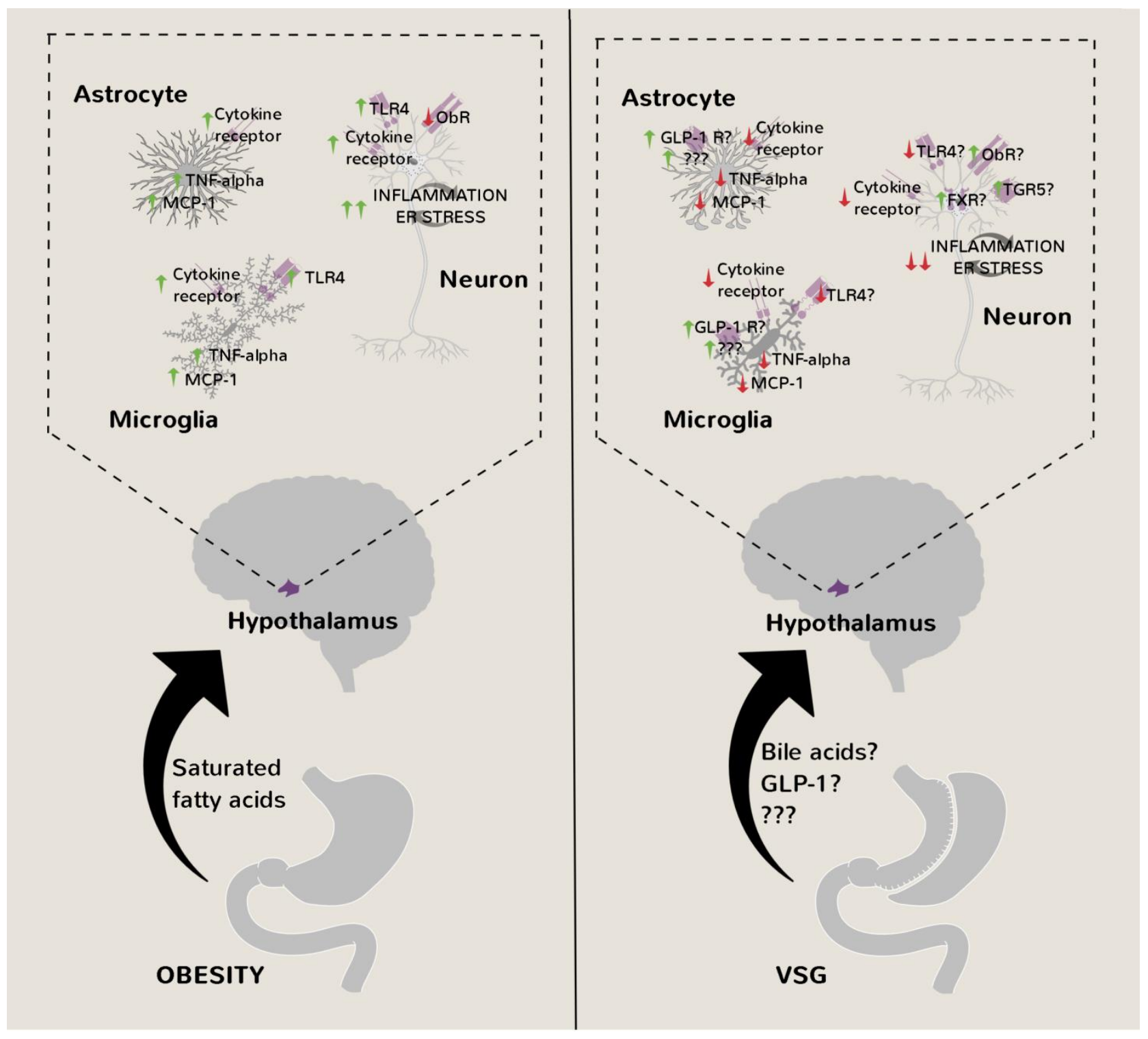

FIGURE 4: Amelioration of hypothalamic inflammation, ER stress and gliosis after VSG. After VSG, activation of FXR/TGR5 in hypothalamic neurons from the rise in circulating bile acids, and GLP-1 receptors in hypothalamic glial cells from the rise in circulating GLP-1, may contribute to amelioration of inflammatory processes, ER stress, gliosis and leptin resistance in obesity, thereby potentially contributing to reduced food intake and lasting weight loss. FXR - farnesoid X receptor, GLP-1 - glucagon-like peptide 1, ObR - leptin receptor, MCP-1 monocyte chemoattractant protein 1, TGR5 - Takeda G-protein 5 receptor, TLR4 - toll-like receptor 4, TNF-alpha - tumor necrosis factor alpha, VSG - vertical sleeve gastrectomy. 
Further questions still remain of course such as the definitive nature of the anti-inflammatory/ER stress relieving gut-derived factor(s) enhanced after VSG. Bile acids acting on hypothalamic farnesoid $X$ receptors (FXR) and/or Takeda G-protein 5 receptors (TGR5) [49-52] are possible candidates as they are essential for the reduced food intake and body weight postoperatively [42, 53, 54]. In this context, bile acids would conceivably be mediating their effects through FXR and TGR5 in hypothalamic neurons and not glial cells $[52,55]$. On the other hand, enhanced GLP-1 receptor signaling in hypothalamic astrocytes [56] and/or microglia [57] could explain their reduced activation after VSG thereby contributing to weight loss but again this is not supported by studies on germline GLP-1 receptor deficient mice [58]. Nevertheless, post-embryonic hypothalamic microglial/astrocytic ablation approaches [ 25 $28,29]$ may yield different findings.

\section{CONCLUSIONS AND FUTURE DIRECTIONS}

The fact that chemical hypothalamic ER stress relievers and VSG both can reverse a pathologic brain state in animal models of obesity suggests that rather than just treating its symptoms, they tackle it at one of its root causes. Future work will be required to verify if the promising animal findings can be translated to humans. For example, assessing human hypothalamic gliosis through the use of T2weighted magnetic resonance imaging [59] or more directly with positron emission tomography [60] may reveal if
VSG has an inhibitory effect. Furthermore, patients with higher levels of hypothalamic gliosis may respond better to VSG which would take us one step closer to personalized treatment options for individuals with severe obesity.

\section{ACKNOWLEDGMENTS}

FS receives funding from the German Research Foundation (DFG) grant number 271722282. MKH has received funding from the DFG Collaborative Research Centre (CRC) 1052 in Obesity Mechanisms (Project A8). MKH is grateful to Prof. Matthias Blüher for continued support. The figures for this manuscript were produced using Mind the Graph software.

\section{CONFLICT OF INTEREST}

The authors have no conflicts of interest to declare.

\section{COPYRIGHT}

(C) 2019 Seyfried and Hankir. This is an open-access article released under the terms of the Creative Commons Attribution (CC BY) license, which allows the unrestricted use, distribution, and reproduction in any medium, provided the original author and source are acknowledged.

Please cite this article as: Florian Seyfried and Mohammed K. Hankir (2019). Could de-stressing the brain be the solution for long-term weight loss? Cell Stress 3(2): 29-37. doi: 10.15698/cst2019.02.174

7. Hotamisligil GS, Peraldi P, Budavari A, Ellis R, White MF, Spiegelman BM (1996). IRS-1-mediated inhibition of insulin receptor tyrosine kinase activity in TNF-alpha- and obesity-induced insulin resistance. Science 271(5249):665-8. doi: 10.1126/science.271.5249.665

8. Luck H, Tsai S, Chung J, Clemente-Casares X, Ghazarian M, Revelo XS, Lei H, Luk CT, Shi SY, Surendra A, Copeland JK, Ahn J, Prescott D, Rasmussen BA, Chng MH, Engleman EG, Girardin SE, Lam TK, Croitoru K, Dunn S, Philpott DJ, Guttman DS, Woo M, Winer S, Winer DA (2015). Regulation of obesity-related insulin resistance with gut antiinflammatory agents. Cell Metab 21(4):527-42. doi: 10.1016/j.cmet.2015.03.001

9. Shi H, Kokoeva MV, Inouye K, Tzameli I, Yin H, Flier JS (2006). TLR4 links innate immunity and fatty acid-induced insulin resistance. J Clin Invest 116(11):3015-25. doi: 10.1172/JCI28898

10. Zhang Y, Proenca R, Maffei M, Barone M, Leopold L, Friedman JM (1994). Positional cloning of the mouse obese gene and its human homologue. Nature 372(6505):425-32. doi: 10.1038/372425a0

4. Nishimura S, Manabe I, Nagasaki M, Eto K, Yamashita H, Ohsugi M, Otsu M, Hara K, Ueki K, Sugiura S, Yoshimura K, Kadowaki T, Nagai R (2009). CD8+ effector $T$ cells contribute to macrophage recruitment and adipose tissue inflammation in obesity. Nat Med 15(8):914-20. doi: 10.1038/nm.1964

5. Duffaut C, Galitzky J, Lafontan M, Bouloumié A (2009). Unexpected trafficking of immune cells within the adipose tissue during the onset of obesity. Biochem Biophys Res Commun 384(4):482-5. doi: 10.1016/j.bbrc.2009.05.002

6. Weisberg SP, McCann D, Desai M, Rosenbaum M, Leibel RL, Ferrante AW Jr (2003). Obesity is associated with macrophage accumulation in adipose tissue. J Clin Invest 112(12):1796-808. doi:10.1172/jci19246
11. Heymsfield SB, Greenberg AS, Fujioka K, Dixon RM, Kushner R, Hunt T, Lubina JA, Patane J, Self B, Hunt P, McCamish M (1999) Recombinant leptin for weight loss in obese and lean adults: a randomized, controlled, dose-escalation trial. JAMA 282(16):1568-75. doi: 10.1001/jama.282.16.1568

12. Zhang $X$, Zhang G, Zhang $H$, Karin M, Bai H, Cai D (2008). Hypothalamic IKKbeta/NF-kappaB and ER stress link overnutrition to energy imbalance and obesity. Cell 135(1):61-73. doi: 10.1016/j.cell.2008.07.043

13. Ozcan L, Ergin AS, Lu A, Chung J, Sarkar S, Nie D, Myers MG Jr, Ozcan U (2009). Endoplasmic reticulum stress plays a central role in 
development of leptin resistance. Cell Metab 9(1):35-51. doi: 10.1016/j.cmet.2008.12.004

14. Zabolotny JM, Kim YB, Welsh LA, Kershaw EE, Neel BG, Kahn BB (2008). Protein-tyrosine phosphatase $1 B$ expression is induced by inflammation in vivo. J Biol Chem283(21):14230-41. doi: 10.1074/jbc.m800061200

15. Zhang ZY, Dodd GT, Tiganis T (2015). Protein Tyrosine Phosphatases in Hypothalamic Insulin and Leptin Signaling. Trends Pharmacol Sci 36(10):661-674. doi:10.1016/j.tips.2015.07.003

16. Gu F, Nguyên DT, Stuible $M$, Dubé $N$, Tremblay $M L$, Chevet $E$ (2004). Protein-tyrosine phosphatase 1B potentiates IRE1 signaling during endoplasmic reticulum stress. J Biol Chem 279(48):49689-93. doi: $10.1074 /$ jbc.c400261200

17. Andrews M, Arredondo M (2012). Hepatic and adipocyte cells respond differentially to iron overload, hypoxic and inflammatory challenge. Biometals 25(4):749-59. doi:10.1007/s10534-012-9543-9. doi: 10.1007/s10534-012-9543-9

18. Münzberg H, Myers MG Jr (2005). Molecular and anatomical determinants of central leptin resistance. Nat Neurosci 8(5):566-70. doi:10.1038/nn1454

19. Schneeberger $M$, Dietrich MO, Sebastián $D$, Imbernón $M$, Castaño C, Garcia A, Esteban Y, Gonzalez-Franquesa A, Rodríguez IC, Bortolozzi A, Garcia-Roves PM, Gomis R, Nogueiras R, Horvath TL, Zorzano A, Claret $M$ (2013). Mitofusin 2 in POMC neurons connects ER stress with leptin resistance and energy imbalance. Cell 155(1):172-87. doi:10.1016/j.cell.2013.09.003

20. Sasaki A, Inagaki-Ohara K, Yoshida T, Yamanaka A, Sasaki M, Yasukawa $H$, Koromilas $A E$, Yoshimura $A$ (2003). The N-terminal truncated isoform of SOCS3 translated from an alternative initiation AUG codon under stress conditions is stable due to the lack of a major ubiquitination site, Lys-6. J Biol Chem 278(4):2432-6. doi:10.1074/jbc.C200608200

21. Thaler JP, Yi CX, Schur EA, Guyenet SJ, Hwang BH, Dietrich MO, Zhao X, Sarruf DA, Izgur V, Maravilla KR, Nguyen HT, Fischer JD, Matsen ME, Wisse BE, Morton GJ, Horvath TL, Baskin DG, Tschöp MH Schwartz MW (2012). Obesity is associated with hypothalamic injury in rodents and humans. J Clin Invest 122(1):153-62. doi: 10.1172/jci59660

22. Milanski M, Degasperi G, Coope A, Morari J, Denis R, Cintra DE, Tsukumo DM, Anhe G, Amaral ME, Takahashi HK, Curi R, Oliveira HC, Carvalheira JB, Bordin S, Saad MJ, Velloso LA (2009). Saturated fatty acids produce an inflammatory response predominantly through the activation of TLR4 signaling in hypothalamus: implications for the pathogenesis of obesity. J Neurosci 29(2):359-70. doi: 10.1523/jneurosci.2760-08.2009

23. Kleinridders A, Schenten D, Könner AC, Belgardt BF, Mauer J, Okamura T, Wunderlich FT, Medzhitov R, Brüning JC (2009). MyD88 signaling in the CNS is required for development of fatty acid-induced leptin resistance and diet-induced obesity. Cell Metab 10(4):249-59. doi: 10.1016/j.cmet.2009.08.013

24. Valdearcos M, Robblee MM, Benjamin DI, Nomura DK, Xu AW, Koliwad SK (2014). Microglia dictate the impact of saturated fat consumption on hypothalamic inflammation and neuronal function. Cell Rep 9(6):2124-38. doi: 10.1016/j.celrep.2014.11.018

25. Valdearcos $M$, Douglass JD, Robblee MM, Dorfman MD, Stifler DR, Bennett ML, Gerritse I, Fasnacht R, Barres BA, Thaler JP, Koliwad SK (2018). Microglial Inflammatory Signaling Orchestrates the Hypothalamic Immune Response to Dietary Excess and Mediates Obesity Susceptibility. Cell Metab 26(1):185-197.e3. doi: 10.1016/j.cmet.2017.05.015
26. Dorfman MD, Krull JE, Douglass JD, Fasnacht $R$, Lara-Lince $F$, Meek TH, Shi X, Damian V, Nguyen HT, Matsen ME, Morton GJ, Thaler JP (2017). Sex differences in microglial CX3CR1 signalling determine obesity susceptibility in mice. Nat Commun 8:14556. doi: 10.1038/ncomms14556

27. Morari J, Anhe GF, Nascimento LF, de Moura RF, Razolli D, Solon C, Guadagnini D, Souza G, Mattos AH, Tobar N, Ramos CD, Pascoal VD, Saad MJ, Lopes-Cendes I, Moraes JC, Velloso LA (2014). Fractalkine (CX3CL1) is involved in the early activation of hypothalamic inflammation in experimental obesity. Diabetes 63(11):3770-84. doi: $10.2337 / \mathrm{db} 13-1495$

28. Zhang Y, Reichel JM, Han C, Zuniga-Hertz JP, Cai D (2017). Astrocytic Process Plasticity and IKK $\beta / N F-K B$ in Central Control of Blood Glucose, Blood Pressure, and Body Weight. Cell Metab 25(5):10911102.e4. doi: 10.1016/j.cmet.2017.04.002

29. Douglass JD, Dorfman MD, Fasnacht R, Shaffer LD, Thaler JP (2017). Astrocyte IKK $\beta / N F-K B$ signaling is required for diet-induced obesity and hypothalamic inflammation. Mol Metab 6(4):366-373. doi: 10.1016/j.molmet.2017.01.010

30. Williams KW, Liu T, Kong X, Fukuda $M$, Deng $Y$, Berglund ED, Deng Z, Gao Y, Liu T, Sohn JW, Jia L, Fujikawa T, Kohno D, Scott MM, Lee S, Lee CE, Sun K, Chang Y, Scherer PE, Elmquist JK (2014). Xbp1s in Pomc neurons connects ER stress with energy balance and glucose homeostasis. Cell Metab 20(3):471-82. doi: 10.1016/j.cmet.2014.06.002

31. Liu J, Lee J, Salazar Hernandez MA, Mazitschek R, Ozcan U (2015). Treatment of obesity with celastrol. Cell 161(5):999-1011. doi: 10.1016/j.cell.2015.05.011

32. Lamb J, Crawford ED, Peck D, Modell JW, Blat IC, Wrobel MJ, Lerner J, Brunet JP, Subramanian A, Ross KN, Reich $M$, Hieronymus $H$, Wei G, Armstrong SA, Haggarty SJ, Clemons PA, Wei R, Carr SA, Lander ES, Golub TR (2006). The Connectivity Map: using gene-expression signatures to connect small molecules, genes, and disease. Science 313(5795):1929-35. doi: 10.1126/science.1132939

33. Dhillon H, Zigman JM, Ye C, Lee CE, McGovern RA, Tang V, Kenny $\mathrm{CD}$, Christiansen LM, White RD, Edelstein EA, Coppari R, Balthasar $\mathrm{N}$ Cowley MA, Chua S Jr, Elmquist JK, Lowell BB (2006). Leptin directly activates SF1 neurons in the VMH, and this action by leptin is required for normal body-weight homeostasis. Neuron 49(2):191-203 doi 10.1016/j.neuron.2005.12.021

34. Lee J, Liu J, Feng X, Salazar Hernández MA, Mucka P, Ibi D, Choi $J W$, Ozcan $U$ (2016). Withaferin A is a leptin sensitizer with strong antidiabetic properties in mice. Nat Med 22(9):1023-32. doi: $10.1038 / \mathrm{nm} .4145$

35. Lee $\mathrm{JH}$, Koo TH, Yoon $\mathrm{H}$, Jung $\mathrm{HS}$, Jin HZ, Lee $\mathrm{K}$, Hong YS, Lee JJ (2006). Inhibition of NF-kappa B activation through targeting I kappa B kinase by celastrol, a quinone methide triterpenoid. Biochem Pharmacol 72(10):1311-21. doi: 10.1016/j.bcp.2006.08.014

36. Kyriakou E, Schmidt S, Dodd GT, Pfuhlmann K, Simonds SE, Lenhart D, Geerlof A, Schriever SC, De Angelis M, Schramm KW, Plettenburg O, Cowley MA, Tiganis T, Tschöp MH, Pfluger PT, Sattler M, Messias AC (2018). Celastrol Promotes Weight Loss in Diet-Induced Obesity by Inhibiting the Protein Tyrosine Phosphatases PTP1B and TCPTP in the Hypothalamus. J Med Chem 61(24): 11144-11157. doi: 10.1021/acs.jmedchem.8b01224

37. Ma X, Xu L, Alberobello AT, Gavrilova O, Bagattin A, Skarulis M, Liu J, Finkel T, Mueller E (2015). Celastrol Protects against Obesity and Metabolic Dysfunction through Activation of a HSF1-PGC1 $\alpha$ Transcriptional Axis. Cell Metab 22(4):695-708. doi 10.1016/j.cmet.2015.08.005.

38. Pfuhlmann K, Schriever SC, Baumann P, Kabra DG, Harrison L, Mazibuko-Mbeje SE, Contreras RE, Kyriakou E, Simonds SE, Tiganis T, Cowley MA, Woods SC, Jastroch M, Clemmensen C, De Angelis M, 
Schramm KW, Sattler M, Messias AC, Tschöp MH, Pfluger PT (2018). Celastrol-Induced Weight Loss Is Driven by Hypophagia and Independent From UCP1. Diabetes 67(11):2456-2465. doi: 10.2337/db18-0146

39. Xiang J, Bian C, Wan X, Zhang Q, Huang S, Wu D (2018). Sleeve Gastrectomy Reversed Obesity-Induced Hypogonadism in a Rat Model by Regulating Inflammatory Responses in the Hypothalamus and Testis. Obesity Surgery 28(8):2272-2280. doi: 10.1007/s11695-018-3150y

40. McGavigan AK, Henseler ZM, Garibay D, Butler SD, Jayasinghe S, Ley RE, Davisson RL, Cummings BP (2017). Vertical sleeve gastrectomy reduces blood pressure and hypothalamic endoplasmic reticulum stress in mice. Dis Model Mech 10(3):235-243. doi: 10.1242/dmm.027474

41. Ding $L$, Sousa KM, Jin L, Dong B, Kim BW, Ramirez R, Xiao Z, Gu Y, Yang Q, Wang J, Yu D, Pigazzi A, Schones D, Yang L, Moore D, Wang Z, Huang W (2016). Vertical sleeve gastrectomy activates GPBAR-1/TGR5 to sustain weight loss, improve fatty liver, and remit insulin resistance in mice. Hepatology 64(3):760-73. doi: 10.1002/hep.28689

42. Chen Y, Yang J, Nie X, Song Z, Gu Y (2018). Effects of Bariatric Surgery on Change of Brown Adipocyte Tissue and Energy Metabolism in Obese Mice. Obesity Surgery 28(3):820-830. doi: 10.1007/s11695017-2899-8

43. Moncada R, Becerril S, Rodríguez A, Méndez-Giménez $L$, Ramírez $B$, Catalán V, Gómez-Ambrosi J, Gil MJ, Fernández S, Cienfuegos JA, Valentí V, Frühbeck G (2016). Sleeve Gastrectomy Reduces Body Weight and Improves Metabolic Profile also in Obesity-Prone Rats. Obesity Surgery 26(7):1537-48. doi: 10.1007/s11695-015-1915-0

44. Jahansouz C, Xu H, Hertzel AV, Kizy S, Steen KA, Foncea R, Serrot FJ Kvalheim N, Luthra G, Ewing K, Leslie DB, Ikramuddin S, Bernlohr DA (2018). Partitioning of adipose lipid metabolism by altered expression and function of PPAR isoforms after bariatric surgery. Int J Obes42(2):139-146. doi: 10.1038/ijo.2017.197

45. Stefater MA, Pérez-Tilve $D$, Chambers AP, Wilson-Pérez HE, Sandoval DA, Berger J, Toure M, Tschöp M, Woods SC, Seeley RJ (2010). Sleeve gastrectomy induces loss of weight and fat mass in obese rats, but does not affect leptin sensitivity. Gastroenterology 138(7):242636, 2436.e1-3. doi: 10.1053/j.gastro.2010.02.059

46. Arble DM, Schwartz AR, Polotsky VY, Sandoval DA, Seeley RJ (2019). Vertical sleeve gastrectomy improves ventilatory drive through a leptin-dependent mechanism. JCI Insight 4(1). pii: 124469. doi: 10.1172/jci.insight.124469

47. Lopez PP, Nicholson SE, Burkhardt GE, Johnson RA, Johnson FK (2009). Development of a sleeve gastrectomy weight loss model in obese Zucker rats. The Journal of Surgical Research 157(2):243-50. doi: 10.1016/j.jss.2008.10.025

48. Li F, Sheng C, Song K, Zhang M, Bu L, Yang P, Sheng H, Li H, Qu S (2016). Preventative Sleeve Gastrectomy Contributes to Maintaining $\beta$ Cell Function in db/db Diabetic Mouse. Obesity Surgery 26(10):240210. doi: 10.1007/s11695-016-2112-5

49. Gofflot F, Chartoire N, Vasseur L, Heikkinen S, Dembele D, Le Merrer J, Auwerx J (2007). Systematic gene expression mapping clusters nuclear receptors according to their function in the brain. Cell 131(2):405-18. doi:10.1016/j.cell.2007.09.012
50. La Frano MR, Hernandez-Carretero A, Weber N, Borkowski K, Pedersen TL, Osborn O, Newman JW (2017) Diet-induced obesity and weight loss alter bile acid concentrations and bile acid-sensitive gene expression in insulin target tissues of C57BL/6J mice. Nutr Res 46:1121. doi: 10.1016/j.nutres.2017.07.006

51. Cummings BP, Bettaieb A, Graham JL, Kim J, Ma F, Shibata N, Stanhope KL, Giulivi C, Hansen F, Jelsing J, Vrang N, Kowala M, Chouinard ML, Haj FG, Havel PJ (2013). Bile-acid-mediated decrease in endoplasmic reticulum stress: a potential contributor to the metabolic benefits of ileal interposition surgery in UCD-T2DM rats. Dis Model Mech 6(2):443-56. doi: 10.1242/dmm.010421

52. McMillin M, Frampton G, Tobin R, Dusio G, Smith J, Shin H, NewellRogers K, Grant S, DeMorrow S (2015). TGR5 signaling reduces neuroinflammation during hepatic encephalopathy. J Neurochem 135(3):565-76. doi: 10.1111/jnc.13243

53. Ryan KK, Tremaroli V, Clemmensen C, Kovatcheva-Datchary $P$, Myronovych A, Karns R, Wilson-Pérez HE, Sandoval DA, Kohli R, Bäckhed F, Seeley RJ (2014) FXR is a molecular target for the effects of vertical sleeve gastrectomy. Nature 509(7499):1838.doi:10.1038/nature13135

54. McGavigan AK, Garibay D, Henseler ZM, Chen J, Bettaieb A, Haj FG, Ley RE, Chouinard ML, Cummings BP (2017). TGR5 contributes to glucoregulatory improvements after vertical sleeve gastrectomy in mice. Gut 66(2):226-234. doi: 10.1136/gutjnl-2015-309871

55. Albrecht S, Fleck AK, Kirchberg I, Hucke S, Liebmann M, Klotz L, Kuhlmann $T$ (2017) Activation of FXR pathway does not alter glial cell function. J Neuroinflammation 14(1):66. doi: 10.1186/s12974-0170833-6

56. Iwai T, Ito S, Tanimitsu K, Udagawa S, Oka J (2006) Glucagon-like peptide-1 inhibits LPS-induced IL-1beta production in cultured rat astrocytes. Neurosci Res 55(4):352-60. doi 10.1016/j.neures.2006.04.008

57. Activation of Glucagon-Like Peptide-1 Receptor Promotes Neuroprotection in Experimental Autoimmune Encephalomyelitis by Reducing Neuroinflammatory Responses (2018). Lee $\mathrm{CH}$, Jeon SJ, Cho KS, Moon E, Sapkota A, Jun HS, Ryu JH, Choi JW. Mol Neurobiol 55(4):3007-3020. doi: 10.1007/s12035-017-0550-2

58. Wilson-Pérez HE, Chambers AP, Ryan KK, Li B, Sandoval DA, Stoffers D, Drucker DJ, Pérez-Tilve D, Seeley RJ (2013) Vertical sleeve gastrectomy is effective in two genetic mouse models of glucagon-like Peptide 1 receptor deficiency. Diabetes 62(7):2380-5. doi $10.2337 / \mathrm{db} 12-1498$

59. Schur EA, Melhorn SJ, Oh SK, Lacy JM, Berkseth KE, Guyenet SJ, Sonnen JA, Tyagi V, Rosalynn M, De Leon B, Webb MF, Gonsalves ZT, Fligner CL, Schwartz MW, Maravilla KR (2015). Radiologic evidence that hypothalamic gliosis is associated with obesity and insulin resistance in humans. Obesity 23(11):2142-8. doi: 10.1002/oby.21248

60. Sandiego CM, Gallezot J, Pittman B, Nabulsi N, Lim K, Lin S, Matuskey D, Lee J, O'Connor KC, Huang Y, Carson RE, Hannestad J, Cosgrove KP (2015). Imaging robust microglial activation after lipopolysaccharide administration in humans with PET. Proc Natl Acad Sci U S A 112(40): 12468-12473. doi: 10.1073/pnas.1511003112 